\title{
Thrift and Credit Cooperative Lending Channels under Prolonged Low Interest Rates: The Case of Thailand
}

\author{
Associate Professor Kovit Charnvitayapong, Ph.D. \\ Faculty of Economics, Thammasat University, Bangkok 10200, Thailand \\ https://doi.org/10.35609/gcbssproceeding.2020.11(1)
}

\begin{abstract}
Since the global financial crisis of 2007-08, the United States, Japan, and the European Union (EU) have heavily stimulated their economies with expansionary monetary policy. World finance has been affected by this policy conduct. Interest rates in most open economies were pushed to very low levels and have remained low ever since. Nevertheless, monetary stimulation has not improved the economic situation to a satisfactory level as of the end of 2019. Several studies such as Claudio Borio and Boris Hofmann (2017) and Nasha Ananchotikul and Dulani Seneviratne (2015) attempted to examine the inefficiency of expansionary monetary policy by looking at bank lending channels. Koot and Walker (1980) studied monetary policy effectiveness through credit union lending channels. They found that at first, credit unions responded well to expansionary monetary policy, but after prolonged easy money policy, the response died down.
\end{abstract}

Keywords: Fixed effects, Lending channel, Prolonged low interest rates, Thrift and credit cooperatives (TCCs), Transmission mechanism. 